\title{
Physical Distancing in Small Industries to Prevent COVID-19 in New Normal Era Case Study: Workstation Canting at Batik Tulis Workshop in Central Java
}

\author{
Rachmi Kumala Widyasari $^{1^{*}} \quad$ Agus Sachari $^{2} \quad$ Andar Bagus Sriwarno $^{3} \quad$ G. Prasetyo Adhitama ${ }^{4}$ \\ Faculty of Arts and Design, Bandung Institute of Technology \\ Jl. Ganesha No. 10 Bandung, West Java, Indonesia 40132
}

\begin{abstract}
The COVID-19 pandemic has a significant impact on the economic sector, especially small industries. One that feels the impact is the traditional batik industry. In the traditional batik tulis business, the process is still mostly done by humans. One of the most critical processes in the traditional batik tulis is the canting process, and batik workers do it in groups in a canting workstation with the value of togetherness and sharing. However, given the New Normal Era, to prevent the spread of COVID-19, new considerations are needed in arranging workspaces for traditional batik workers. This study aims to provide recommendations for alternative layout compositions of equipment in the workspace, canting workstations, following New Normal standards. This research was conducted through an ethnographic approach with interviews and observations of several batik houses in Central Java. The research continued with experimentation by reconstructing batik activities using canting at the Ergonomics Laboratory, Faculty of Art and Design, Bandung Institute of Technology. The experimental results were then simulated to produce the best layout composition according to the New Normal workspace standards. In conclusion, a circular layout with one stove with a capacity of two batik workers with opposite orientations was the best layout for following physical distancing to prevent the spread of the SARS-COV-2 virus.
\end{abstract}

Keywords: batik tulis, behavior, layout, physical distancing, workstation

DOI: $10.7176 / \mathrm{ADS} / 88-02$

Publication date: December $31^{\text {st }} 2020$

\section{Introduction}

Indonesia's economic sector suffered a significant decline due to the COVID-19 pandemic, especially in micro, small and medium enterprises (Evandio, n.d.). A while ago, the government gradually socialized The New Habit Adaptation in important sectors, including economic and industrial sectors. Offices and industrial estates began to open with security standards imposed following the World Health Organization's direction. In general, preventive measures to prevent COVID-19 are recommended by the WHO (World Health Organization, 2020a). The WHO recommend workers to do their job by always maintaining hand hygiene, using masks, physical distancing, maximizing work from home, regularly cleaning the room using disinfectants, providing information and counseling regarding this pandemic and if there are cases of COVID-19 in the work area then who advises providing special treatment to prevent wider spread immediately.

In the early days of the pandemic, the government encouraged the social distancing movement to prevent the spread of the virus more widely, but now the social distancing movement is turning into physical distancing (Pratomo, 2020). Maria Van Kerkhove, an epidemiologist from WHO, said that "We're changing to say physical distance from social distance and that's on purpose because we want people to stay connected." (World Health Organization, 2020b). Because basically, humans are social beings. Hall explains the discussion of man and distance from a proxemic point of view. Hall said four types of distances informally where this distance depends heavily on personality and environmental factors. The four distances are intimate distance, about 15 to $20 \mathrm{~cm}$, and personal distance is about $45-76 \mathrm{~cm}$, social distance is about $213-365 \mathrm{~cm}$, and public distance $365-762 \mathrm{~cm}$ even above $762 \mathrm{~cm}$ (Hall, 1990).

Meanwhile, in his findings, Sommer also said there is a link between sitting behavior and psychological closeness (Sommer, 2007). This statement is closely related to the WHO's suggestion regarding physical distancing in the work area (World Health Organization, 2020a). In its appeal, the WHO introduced a minimum distance of one meter between people and avoided physical contact. WHO also urged to reduce space users' density in a building with a density rate of one person per $10 \mathrm{~m}^{2}$. Policies on shared spaces and public areas in office areas are also regulated to prevent the spread of viruses in the office area. The weather and room temperature factors also have a significant impact on COVID-19 cases. It is known that an average temperature between $26.1^{\circ} \mathrm{C}$ to $28.6^{\circ} \mathrm{C}$ affects the spread of the SARSCOV-2 virus (Tosepu et al., 2020), while sun exposure is directly known to help the healing process of COVID-19 (Asyary and Veruswati, 2020). Based on this consideration, the Indonesian government adopted it to implement New Habit Adaptation in work and industrial areas (Office of Assistant to Deputy Cabinet Secretary for State Documents \& Translation, 2020). 
One of the affected by the COVID-19 pandemic is the small and home industry, namely the traditional craft industry, especially batik (Kompasiana.com, n.d.) Many batik businesses almost collapse in the early months of the pandemic. Slowly now, about $40 \%$ of batik business in West Java, in particular, is starting to rise (Kurnia, 2020). The implementation of The New Habit Adaptation also began to be implemented for small and home businesses. Therefore, the purpose of this research is to provide a solution through a spatial approach, namely by providing an alternative of layout composition in workstation canting work areas that comply with COVID-19 standards while maintaining traditional work patterns. In the making of batik tulis, the process of batik using canting is critical. Usually, this process does in groups in an area where batik artisans sit while working in a circular setting with a stove as its center to form a working system with the principle of sharing and togetherness while strengthening communication between the workers (Widyasari et al., 2018) - these values to be maintained by keeping the canting workstation layout on the circular pattern.

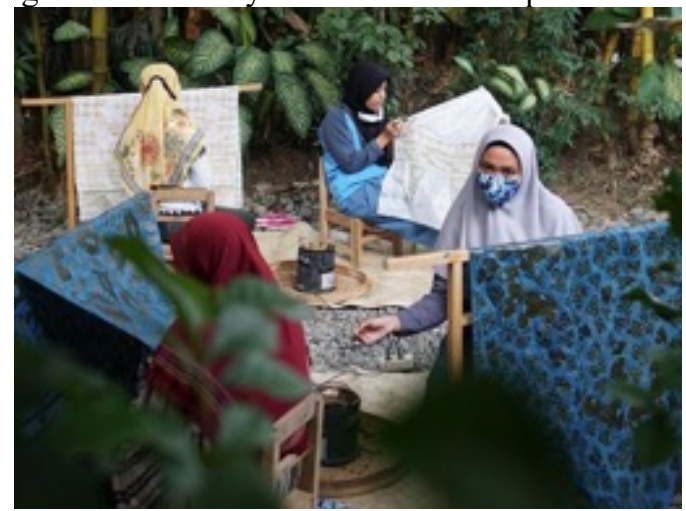

Figure 1. Workstation canting at Galeri Batik Jawa workshop in the new normal era Source: Documentation of Wienand, K. (2020)

\section{Methods}

Research on circular patterns was conducted in several stages at three traditional batik houses, Oey Soe Tjoen batik house in Kedungwuni, Go Tik Swan batik house in Surakarta, and Maranatha batik house in Lasem. The early stages of research are carried out with an ethnographic design approach through interviews and batik artisan's behavior observations in conducting batik process in canting workstations. These interviews and observations were conducted on 12 batik artisans at three research sites. The data was captured through recording with three cameras on a workstation canting with a Camera 1 that observes the batik behavior and the ongoing batik process in close up. Camera 2 observes the batik artisan's behavior and their interactions with other batik artisans in a canting workstation. Camera 3 observes batik artisan behavior and the interaction between the batik process and other workshop processes. The documentation results from three cameras were then analyzed through time and motion study methods (Wignjosoebroto, 2003) through photo and video recordings. Workstation canting, which is standardized for measurement of batik area in this study, is the workstation canting of Go Tik Swan batik house, through consideration that this workstation is well designed, well accessible and can be well documented as shown in the image below.

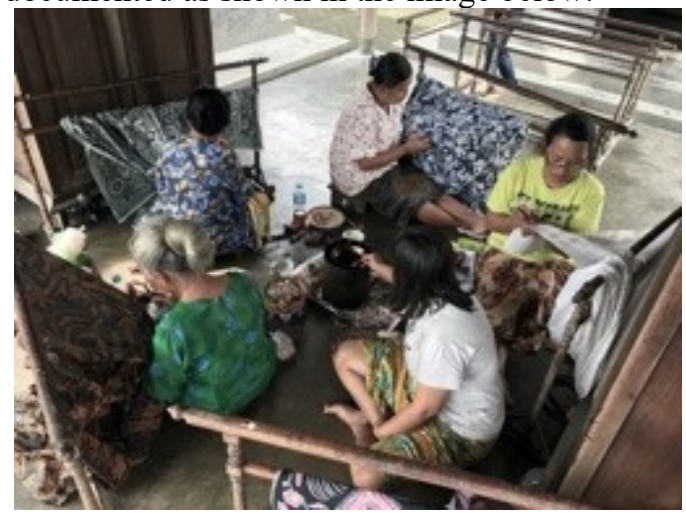

Figure 2. Workstation canting at Go Tik Swan batik workshop before COVID-19

The next stage is the experimentation and reconstruction of the hand movement during the batik process with canting. Reconstruction of this motion was done in the Ergonomics Laboratory Faculty of Art and Design, Bandung Institute of Technology. The experimentation phase begins with the preliminary activity, Ergonomic (Hendrick and Kleiner, 2001) subject. The ergonomic participatory aims to allow the research subject to learn about the batik process using canting directly, with the same tools, and in the same space used by batik artisan in 
batik activities using canting in workstation canting, of Oey Soe Tjoen batik house. Oey Soe Tjoen batik house is a batik house that produces the best Peranakan Batik that is famous to foreign countries (Liong, 2014).

Motion reconstruction is implemented in the Ergonomics Laboratory by a healthy subject and knew the process of batik using canting. This experimentation and motion reconstruction stage using the Qualisys motion capture tool was then analyzed using Qualisys Track Manager software (Qualisys, 2018a) Experimentation begins with the capture of reflective markers at several points at the starting point of measurement, the equipment, and the subject's body. This reflective data marker is captured through eight infrared cameras and an integrated video camera that generates position displacement coordinate data in the X, Y, and Z (Qualisys, 2018b) The marker on the subject's body is affixed, according to point observe of body movement, as to the image:
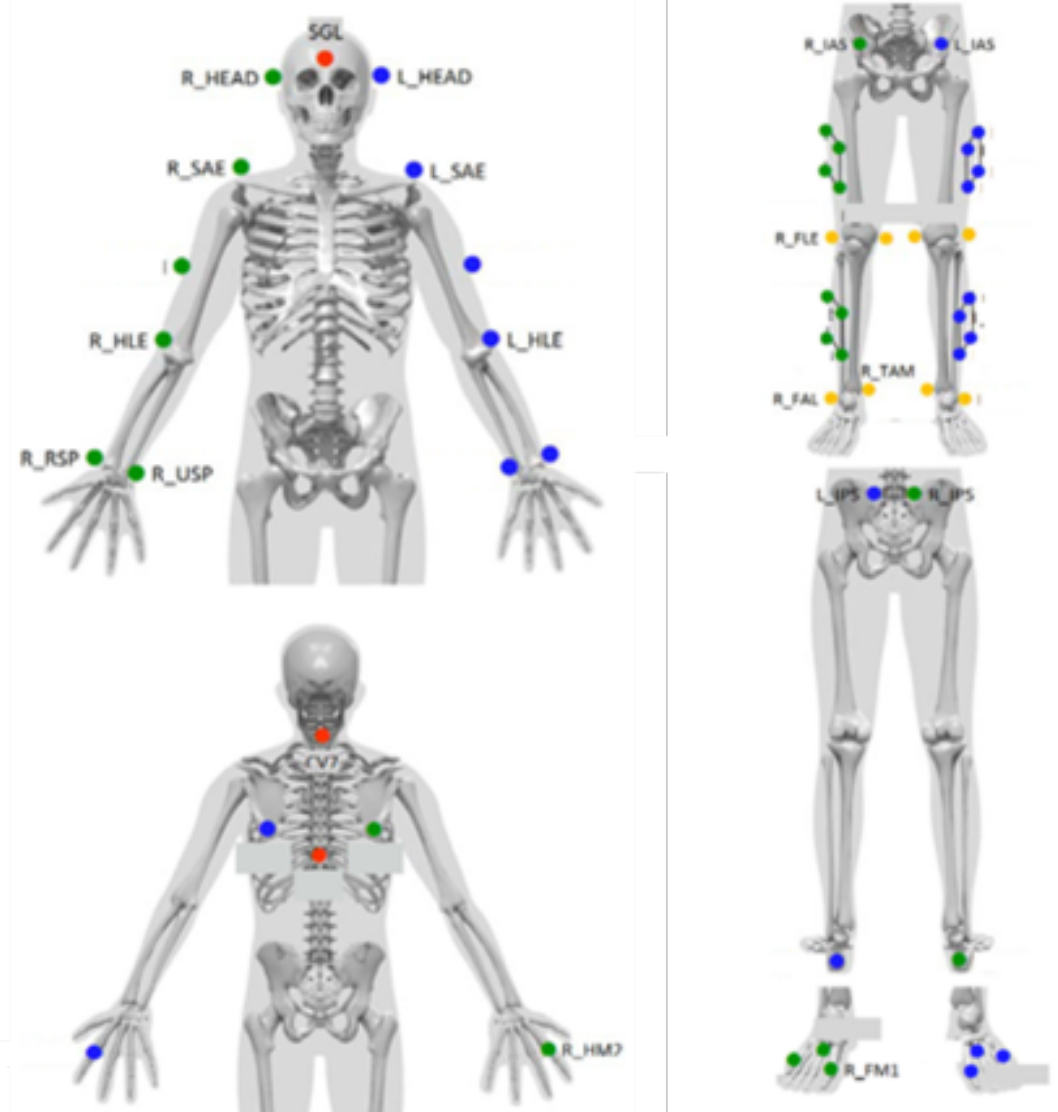

Figure 3. Reference of the placement of markers on the body of the subject

Source: (Cappozzo et al., 1995; van Sint Jan, 2007)

Dots are affixed to the head, neck, and shoulders to track the head and upper body's movement, on the active right hand using a canting tool and on the right foot that is not covered by batik cloth. Based on the above reference, then in the experimentation of the first and second stages, markers are affixed to the point:

1. Glabulla Point - (SGL)

2. Above the right ear Point - (R_HEAD)

3. Above the left ear Point - (L HEAD)

4. Cervical Vertebrae Point $-(\overline{\mathrm{C}} \mathrm{V} 7)$

5. Right Scapula Point - Acromial Edge (R_SAE)

6. Left Scapula Point - Acromial Edge (L SAE)

7. Right Humerus - Lateral Epicondyle Point (R_HLE)

8. Left Humerus - Lateral Epicondyle Point (L_HLE)

9. Right Radius - Styloid Process Point (R_RSP)

10. Right Ulna - Styloid Process Point (R_USP)

11. Right Basis of Forefinger Point (R_HM2)

12. Posterior superior iliac spine Point (IPS)

13. Right anterior superior iliac spine Point (R_IAS)

14. Left anterior superior iliac spine Point (L_IAS)

15. Right lateral epicondyle Point (R_FLE)

16. Right lateral prominence of the lateral malleolus Point (R_FAL)

17. Right medial prominence of the medial malleolus Point ( $\left.\mathrm{R}_{-} \mathrm{TAM}\right)$ 
18. Right Dorsal margin of the first metatarsal head Point(R_FM1)

19. Zero-point on layout near the stove

20. Six points on cloth holder

21. Four points on short seat

22. One point on the fabric

23. Two points on front and back of canting

The subject then asked to perform movements as studied during the Ergonomic Participatory stage, processing batik using canting and hot wax. The movement of these points, particularly the dot's movement on the hands, observed and then seen the pattern to understand the subject's behavior (Camurri et al., 2016)when making batik with canting. The marker at the Front Canting point then becomes a reference to see the Working Envelope based on the movement pattern.
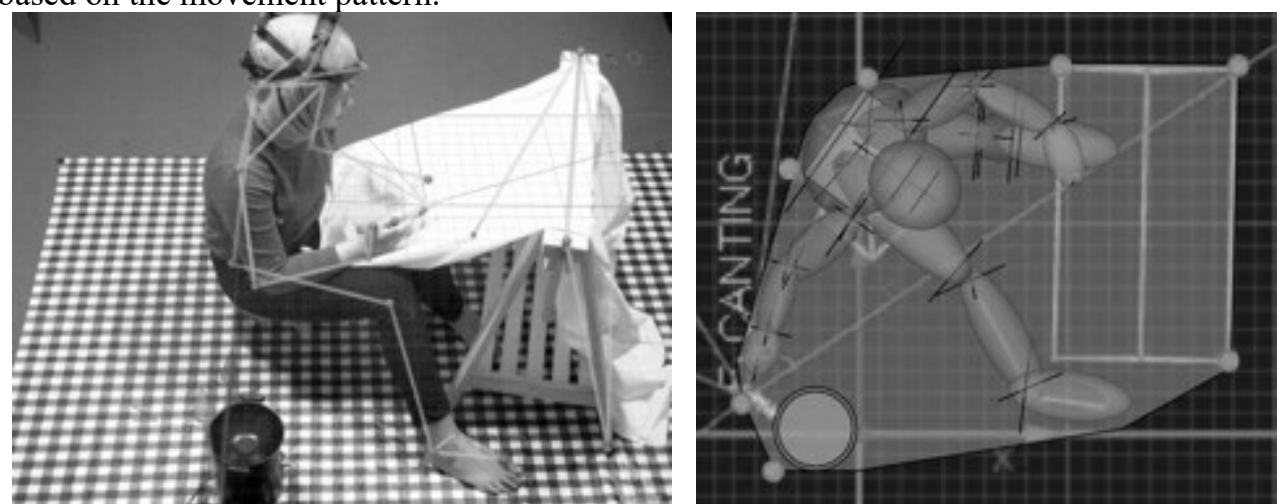

Figure 4. Experiment space layout and marker placement on research subjects and equipment used

Data generated from Qualisys Track Manager software is reconstructed using Sketch Up Software. Through Sketch Up Software, visual data on the movement of subjects and spaces are formed. This visual data is then used as a reference in simulating the best layout composition following physical distancing standards to minimize the spread of the SARSCOV-2 virus.

\section{Results}

The results of observations from workstation canting on batik house Go Tik Swan produce batik area 7,29 $\mathrm{m}^{2}$ with a capacity of 5 batik artisans that surrounds a stove located in the center of the area. So, it can be taken on average that each batik artisan needs $1,458 \mathrm{~m}^{2}$ as a minimum area in working on the batik process using canting. Batik area is dynamic, according to the layout of the equipment and capacity of workers in a workstation, as seen in the following image:

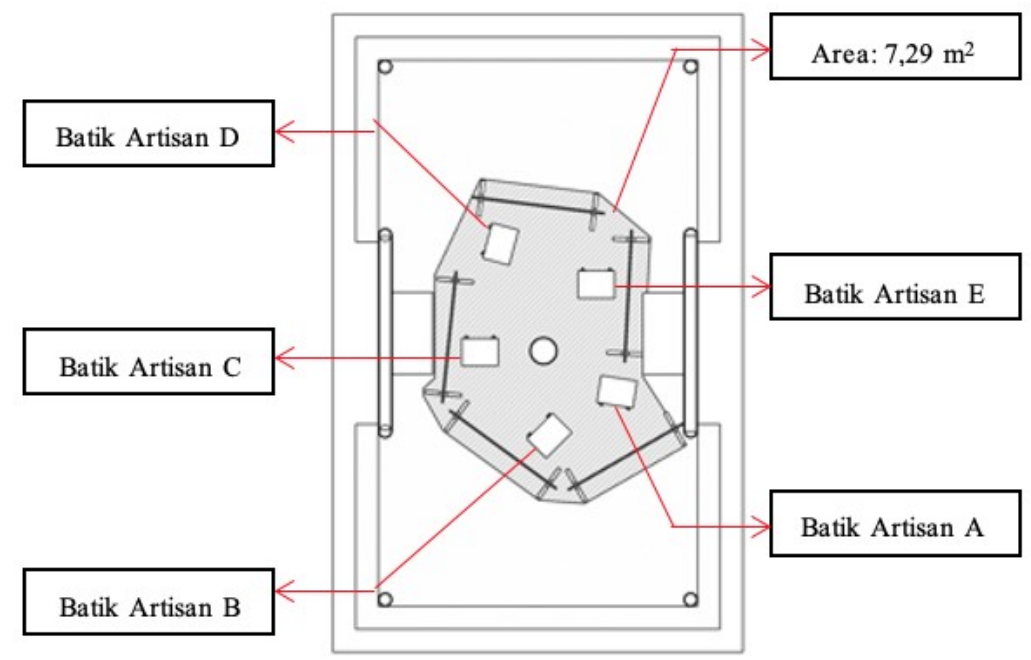

Figure 5. Canting workstation layout and batik area at Go Tik Swan batik house

The experimentation stage was performed twice, and in each experiment was done four times of data retrieval. The result of the reconstruction of the subject's motion is a cycle of movement consisting of four phases, namely:

- Phase 1: The phase of taking the hot wax using the right hand and canting is the initial phase of the batik tulis process. This phase begins with a hand gesture that is already on a stove containing hot wax, then takes the wax using canting. The hand holding the canting then moves closer to the subject. 
- $\quad$ Phase 2: The canting blow phase contains hot wax. This phase is when the hand moves from the stove area towards the subject, stop at a point adjacent to its mouth. The subject then blows the tip of the canting containing a hot wax. This phase aims to lower the hot wax temperature at the end of the canting not to drip easily. After that, the hand then moves closer to the cloth located on the holder.

- Phase 3: The canting phase at the start point on the cloth or fabric. This phase is the phase when canting first incised the hot wax on the fabric.

- Phase 4: The canting phase at the endpoint of the cloth or fabric. This phase was when the canting capacity of wax was reduced, at the endpoint on the fabric, and the hand holding the canting moves back towards the stove.

Phases one through four produce a cycle. This cycle then repeats according to the task to be completed.

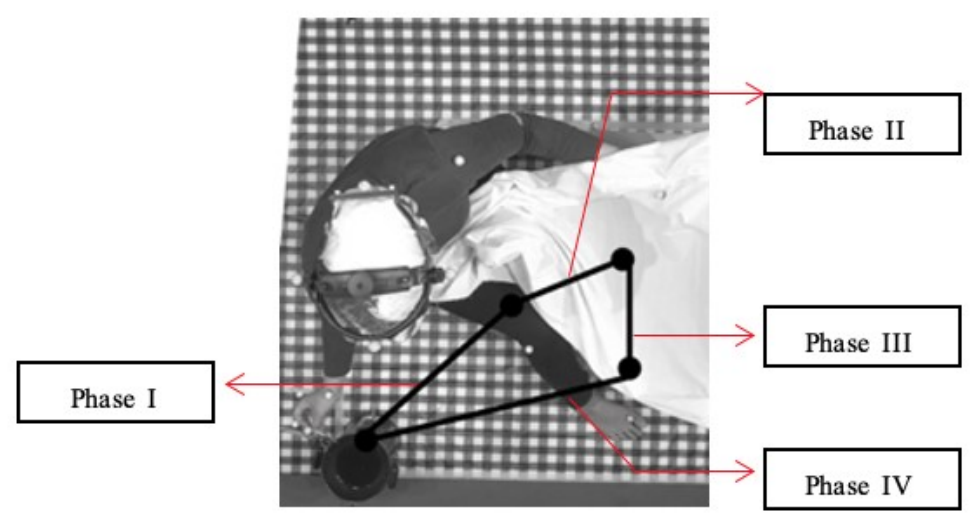

Figure 6. The cycle of hand movement in batik activities with canting

When we look from the top view, the subject's hand movements form a typical motion pattern, forming a field with four sides with varying distances but form curves that tend to be the same. The length of the phase I curve is determined by the distance between the stove and the subject's body position. The length of the phase II curve is determined by the distance of the batik artisan's position with the fabric that becomes the medium in batik. The length of the phase III curve is determined by the length of the fabric's resulting line. As for the last, the phase IV curve's length was determined by the distance of the last point on the fabric with the stove's position. A pattern with four sides formed from these four phases will then be referred to as the Layangan Pattern.

\section{Discussions}

When holding the canting, the hand movement pattern becomes the basis in formulating the working envelope for this type of batik tulis process. The markers' position data is then converted into three-dimensional reconstruction data, both the subject and the equipment. The following is the result of the reconstruction of the subject's postural adaptation and equipment to produce a working area:

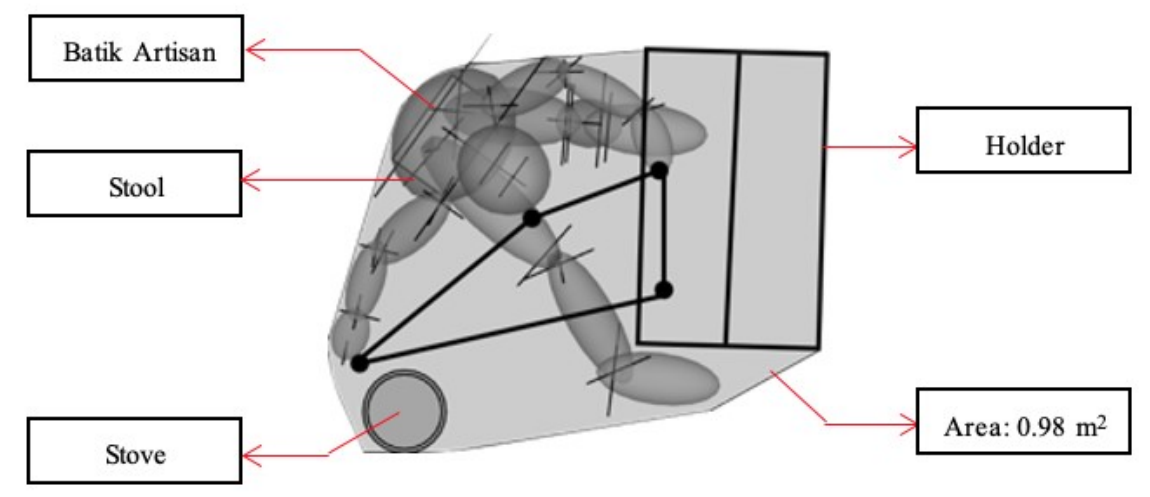

Figure 7. The resulting area of the research subject in batik activity with canting from the top of the

Based on the reconstruction, the order/layout and movement of the subject produce a minimum area for a batik player in the process of batik with a canting area of $0,98 \mathrm{~m}^{2}$. This area's minimum standard is simulated using Sketch Up Software for several possible layouts and batik capacity in a canting workstation. This simulation aims to estimate the safe distance for batik artisans in their work following WHO standars (World Health Organization, 2020a) to anticipate COVID-19 based on distance and motion analysis. Here are simulations of the composition of workstation canting based on the pattern and batik capacity as seen in Table 1: 
Table 1. Alternative layout composition in response to New Habit Adaptations

\begin{tabular}{|c|c|c|c|}
\hline No. & Layout & Capacity & $\begin{array}{l}\text { Area and } \\
\text { Orientation }\end{array}$ \\
\hline 1. & Circular layout with orientation $180^{\circ}$ & 2 & $\begin{array}{l}\text { - Stove as the center. } \\
\text { - Orientation in the } \\
\text { opposite direction } \\
\left(180^{\circ}\right) \text {. } \\
\text { - The circular layout } \\
\text { is devided into two } \\
\text { area. } \\
\text { - Area: } 5,4 \mathrm{~m}^{2}\end{array}$ \\
\hline 2. & Circular layout with orientation $120^{\circ}$ & 3 & $\begin{array}{c}\text { - Stove as the center. } \\
\text { - Orientation: } 120^{\circ} \\
\text { - The circular layout } \\
\text { is devided into three } \\
\text { area. } \\
\text { Area: } 6,6 \mathrm{~m}^{2}\end{array}$ \\
\hline
\end{tabular}




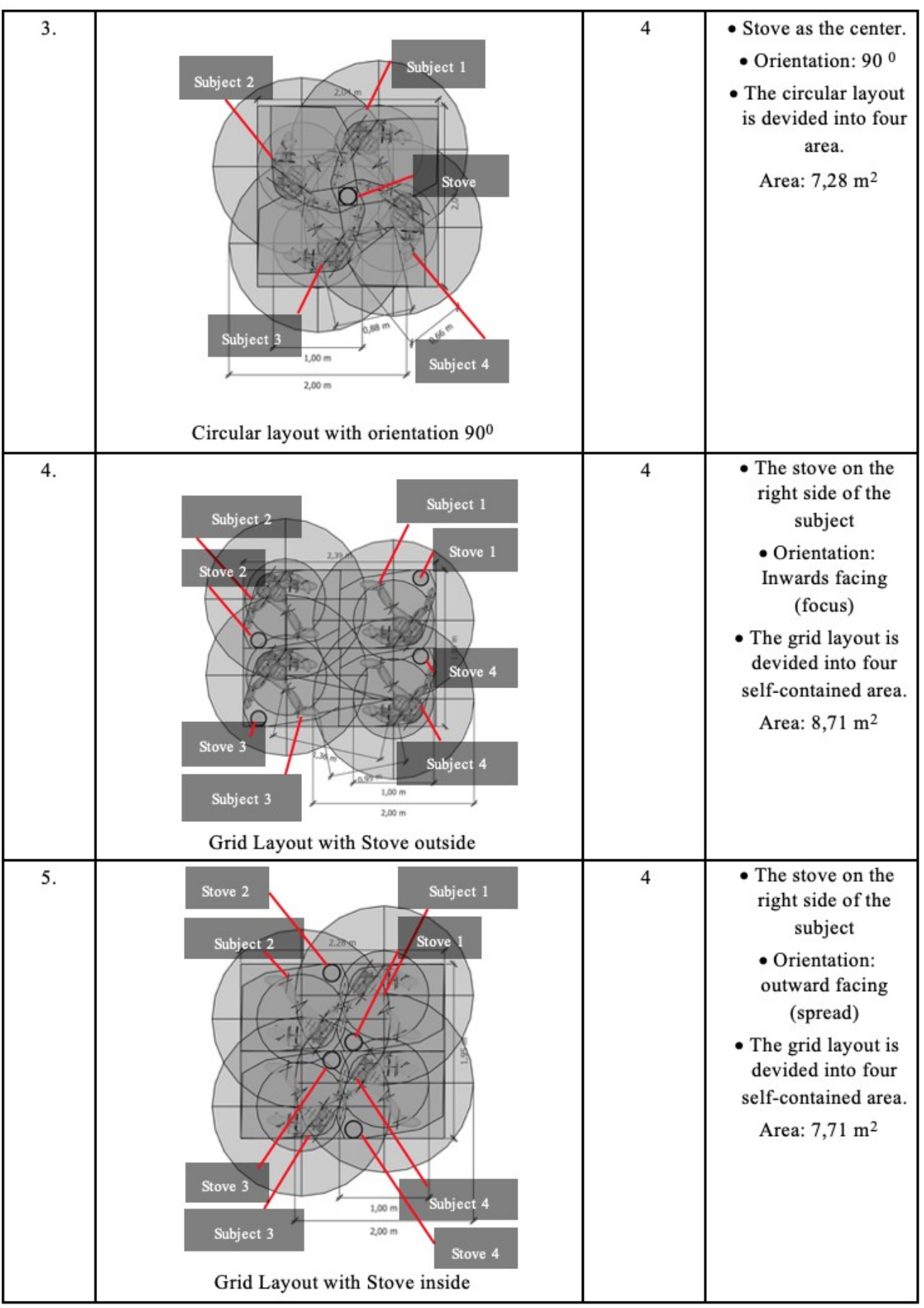

The entire composition of this layout has an imaginary circle centered on the front side of the subject's head, assuming the point as the point of spread of the COVID-19 virus. The circle's diameter varies from 1 meter to 2 meter from its central point, forming an area with a transparent circle based on the safe distance suggested by the WHO in anticipation of the spread of COVID-19 through the droplet.

In the first layout composition, the workstation canting only for two batik artisans with complete equipment, except for the stove used together. The stove located in the center of the workstation layout becomes both a central point and a meeting point for the right hand when taking a hot wax from the stove. Both batik artisans have opposite orientations. The difference in orientation minimizes the virus spreads through droplets because the batik artisan tends to face opposite directions. Nevertheless, imaginary circles to keep a safe distance remain in use while making it clear that circles with a diameter of $1 \mathrm{~m}$ for this composition are not $\mathrm{o}$. Thus, a minimum standard of safety distance of $1 \mathrm{~m}$ is reached. This composition has an excellent psychological closeness relationship, with an adjacent position but a face-to-face (Sommer, 2007)

The second composition is a circular composition with a capacity of three batik artisans. The stove, located 
in the middle of the layout, is still the center point and the meeting point of the batik artisans' hands when taking the wax using canting. This circular layout is divided into three areas with a large angle of $120^{0}$ for each area. The batik artisan orientation leads to the outside of the circle, minimizing the spread of the COVID-19 virus by droplet. However, there is still an overlapping area with a radius of $1 \mathrm{~m}$ in the stove area (center). Meanwhile, in terms of psychological closeness, this angle sitting composition has a pretty good closeness relationship, as does the third composition's angular composition.

The third composition is a circular composition with four batik artisans surrounding a stove at $90^{\circ}$. Circular layout with the stove as its center is the most effective layout (Widyasari et al., 2018) two other types of layouts of the same capacity because of the close distance between batik artisans so that imaginary circles is overlapping, especially in the stove area. Orientation with an angle of $90^{\circ}$ still allows the spread of the COVID-19 virus through the droplet to batik artisans.

The fourth one is a grid composition with four batik artisans equipped with batik equipment independently. The absence of contact area between the batik artisans minimizes the possibility of COVID-19 spread. However, the batik artisans' orientation facing into the layout and proximity can increase the likelihood of the virus's spread through the droplet to the other batik artisan's backside body. From the close relationship psychologically, the composition of sitting next to each other and facing this has an excellent level of closeness. Nevertheless, personally equipped reduces the principle of sharing in the work of cooperation.

The fifth composition is the last composition that becomes a simulation on the proposed layout in the new normal era of New Habits Adaptation in workstation canting. In this layout, batik artisans are equipped with personal batik equipment so that no area is overlapping due to the equipment used together. With an orientation facing out the layout, and an imaginary circle with a minimum radius of $1 \mathrm{~m}$, this layout becomes the most effective layout in anticipation of the spread of the SARS-COV-2 virus. However, when viewed from the relationship of sitting behavior with psychological closeness, the fifth composition is less supportive, and batik tulis personal equipment can reduce the sharing principle that has been one of the traditional work characters.

Therefore, we know the comparison of the area on workstation canting according to layout and capacity, in conditions before COVID-19 and simulation in new normal conditions as seen in the following Table 2:

Table 2. Comparison of the area of workstation canting before COVID-19 and new normal era

\begin{tabular}{|l|l|c|c|l|c|l|}
\hline No. & Layout & Capacity & $\begin{array}{c}\text { Area } \\
\left(\mathbf{m}^{\mathbf{2}}\right)\end{array}$ & Orientation & $\begin{array}{c}\text { Average } \\
\text { Area/Person(m } \mathbf{2})\end{array}$ & Condition \\
\hline 1. & Circular & 5 & 7,29 & Inwards & 1,458 & Before COVID-19 \\
\hline 2. & Circular & 2 & 5,4 & $180^{0}$ & 2,7 & New normal \\
\hline 3. & Circular & 3 & 6,6 & 120 & 2,2 & New normal \\
\hline 4. & Circular & 4 & 7,28 & 90 & 1,82 & New normal \\
\hline 5. & Grid & 4 & 8,71 & Inwards & 2,177 & New normal \\
\hline 6. & Grid & 4 & 7,71 & Outwards & 1,927 & New normal \\
\hline
\end{tabular}

\section{Conclusion}

Produce batik using canting is traditionally maintained for generations. This initially flexible activity for Javanese women is often done together or communally with the family work system. Like other traditional work types, over time, batik's work using canting began to shift to the kind of work that uses more modern tools and technologies. So do the workers. The slow regeneration of the batik artisan resulted in the quantity of traditional batik tulis decreased. Not many young people are interested in pursuing this type of work as a professional.

The COVID-19 pandemic worldwide has impacted the home industry and small industries such as traditional batik tulis businesses. There is a perceived impact by this small industry resulting in the production process's paralysis, but some can still survive. The family system embraced by most traditional batik houses is proven to make traditional batik business survive. The reason is that the system is more flexible both in its work system and its operational system. Nevertheless, a few months at the beginning of this pandemic, the paralysis felt also by the batik industry is more due to the lack of market demand and readiness of raw materials, including the production readiness.

Preparation of batik house reopens its business during adaptation of new habits need to be done carefully and following health protocols. New Normal Adaptation protocols suggest using masks in the workplace, maintaining hand hygiene, keeping the distance to prevent the spread of COVID-19, good lighting, and good air circulation. Maximizing airconditioning through additional active blowers as well as the use of partitions on canting workstations is one of the efforts to support health safety and security in the work area. The traditional work that is usually done together and with the principle of sharing, as the batik tulis process, these new layout 
recommendations need to be considered. While maintaining circular layouts, reducing capacity, and changing their orientation, the first composition is the best composition to prevent the spread of COVID-19 in canting workstations with a capacity of only two batik artisans. The next layout composition recommendation is a second alternative, with a circular pattern and a capacity of three batik artisans. This composition will be more effective if using a larger stove to enlarge the diameter of the center area. The last layout recommendation is grid composition with a capacity of 4 batik artisans and an inward facing orientation. The last composition is considered relatively safe because it uses individual equipment to minimize the intersection area between batik artisans.

\section{References}

Asyary, A., Veruswati, M., 2020. Sunlight exposure increased Covid-19 recovery rates: A study in the central pandemic area of Indonesia. Sci. Total Environ. 139016. https://doi.org/10.1016/j.scitotenv.2020.139016

Camurri, A., El Raheb, K., Even-Zohar, O., Ioannidis, Y., Markatzi, A., Matos, J.M., Morley-Fletcher, E., Palacio, P., Romero, M., Sarti, A., Di Pietro, S., Viro, V., Whatley, S., 2016. WhoLoDancE: Towards a methodology for selecting Motion Capture Data across different Dance Learning Practices. ACM Int. Conf. Proceeding Ser. 05-06-July, 1-2. https://doi.org/10.1145/2948910.2948912

Cappozzo, A., Catani, F., Della Croce, U., Leardini, A., 1995. Position and orientation in space of bones during movement: anatomical frame definition and determination. Clin. Biomech. 10, 171-178.

Evandio, A., n.d. Ini Sektor UMKM yang Meroket dan Tertekan Selama Pandemi Covid-19 [WWW Document]. URL https://ekonomi.bisnis.com/read/20200611/12/1251486/ini-sektor-umkm-yang-meroket-dantertekan-selama-pandemi-covid-19 (accessed 9.1.20).

Hall, E.T., 1990. The Hidden Dimension, Anchor Boo. ed. Anchor Books, a Division of Random House Inc., New York.

Hendrick, H.W., Kleiner, B.M., 2001. Macroergonomics: An introduction to work system design. Human Factors and Ergonomics Society.

Kompasiana.com, n.d. Kondisi Pengrajin Batik di Masa Pandemi Covid-19 [WWW Document]. URL https://www.kompasiana.com/aynad8/5ee1db1fd541df05580f3d32/kondisi-perajin-batik-di-masapandemi-covid-19 (accessed 9.1.20).

Kurnia, K., 2020. Industri dan Pengrajin batik Mulai Bangkit di Tengah Pandemi Covid-19 [WWW Document]. URL https:/galamedia.pikiran-rakyat.com/news/pr-35595307/industri-dan-pengrajin-batik-mulai-bangkitdi-tengah-pandemi-covid-19

Liong, W.K.H., 2014. Oey Soe Tjoen: Duta Batik Peranakan.

Office of Assistant to Deputy Cabinet Secretary for State Documents \& Translation, 2020. Health Minister Issues Guidelines on COVID-19 Prevention at Workplaces [WWW Document]. URL https://setkab.go.id/en/health-minister-issues-guidelines-on-covid-19-prevention-at-workplaces/

Pratomo, H., 2020. From Social Distancing to Physical Distancing: A Challenge for Evaluating Public Health Intervention against COVID-19. Kesmas Natl. Public Heal. J. 60-63. https://doi.org/10.21109/kesmas.v15i2.4010

Qualisys, 2018a. Combining markerless \& marker-based motion capture [WWW Document]. URL https://www.qualisys.com/applications/human-biomechanics/markerless-motion-capture/

Qualisys, 2018b. Analyzing gait with Qualisys 1-4.

Sommer, R., 2007. Personal Space. The Behavioral Basis of Design. ERIC.

Tosepu, R., Gunawan, J., Effendy, D.S., Ahmad, L.O.A.I., Lestari, H., Bahar, H., Asfian, P., 2020. Correlation between weather and Covid-19 pandemic in Jakarta, Indonesia. Sci. Total Environ. 725. https://doi.org/10.1016/j.scitotenv.2020.138436

van Sint Jan, S., 2007. Color Atlas of Skeletal Landmark Definitions E-Book: Guidelines for Reproducible Manual and Virtual Palpations. Elsevier Health Sciences.

Widyasari, R.K., Sriwarno, A.B., Adhitama, G.P., 2018. The Analysis of Centralized Layout on Traditional Batik Tulis Workshop in Central Java, in: The Asian Conference on Arts \& Humanities 2018 Official Conference Proceedings.

Wignjosoebroto, S., 2003. Ergonomi studi gerak dan waktu. Surabaya Guna Widya 283.

World Health Organization, 2020a. Considerations for public health and social measures in the workplace in the context of COVID-19. World Heal. Organ. 1-7.

World Health Organization, 2020b. WHO Audio Emergencies Coronavirus Press Conference 20 March 2020. 